\title{
Erratum to: Access to the ophthalmic artery by retrograde approach through the posterior communicating artery for intra-arterial chemotherapy of retinoblastoma
}

Chi-Tuan Pham • Raphaël Blanc •

Livia Lumbroso-Le Rouic • Silvia Pistocchi •

Bruno Bartolini • Michel Piotin

Published online: 13 December 2011

(C) Springer-Verlag 2011

Erratum to: Neuroradiology

DOI 10.1007/s00234-011-0978-4

The online version of this article unfortunately contained a mistake. The correct abbreviation of the third author's name Livia Lumbroso-Le Rouic is L. Lumbroso-Le Rouic.

The online version of the original article can be found at http://dx.doi. org/10.1007/s00234-011-0978-4.

C.-T. Pham $\cdot$ R. Blanc $(\bowtie) \cdot$ S. Pistocchi $\cdot$ B. Bartolini $\cdot$ M. Piotin Department of Interventional Neuroradiology, Fondation,

Rothschild Hospital,

25 rue Manin,

Paris, France

e-mail: rblanc@fo-rothschild.fr

L. Lumbroso-Le Rouic

Department of Ocular Oncology, Institut Curie,

26 rue d'Ulm,

Paris, France 